\section{PA-566, A Root-knot Nematode-resistant, Pimento-type Pepper}

\author{
Richard L. Fery ${ }^{1}$ and Judy A. Thies \\ U.S. Department of Agriculture, Agricultural Research Service, U.S.
} Vegetable Laboratory, 2700 Savannah Highway, Charleston, SC 294145334

Additional index words. Capsicum annuum, Meloidogyne, pepper breeding
PA-566 is a new pimento-type pepper (Capsicum annuum L.) released 30 Apr. 2010 by the Agricultural Research Service of the U.S. Department of Agriculture. PA566 is the product of a backcross breeding program to incorporate the $N$ root-knot nematode resistance gene into a 'Pimiento L'type genetic background. 'Pimiento $L$ ' is a root-knot nematode-susceptible, pimentotype cultivar that is widely grown in the southern states where it can produce good yields under high-temperature conditions. The dominant $N$ gene conditions a high level of resistance to the southern root-knot nematode [Meloidogyne incognita (Chitwood) Kofoid and White], the peanut root-knot nematode [M. arenaria (Neal) Chitwood], and the tropical root-knot nematode [M. javanica (Treub) Chitwood]. The release of PA-566 will provide pepper breeders interested in developing both open-pollinated and F1 hybrid pimentotype cultivars access to a near-cultivar quality parental line that is homozygous for the $N$ root-knot nematode resistance gene.

\section{Origin}

In 2000, a recurrent backcross breeding procedure was initiated to incorporate the dominant root-knot nematode resistance gene $(N)$ into a 'Pimiento L'-type genetic background (Fig. 1). The donor parent was 'Mississippi Nemaheart' and the recurrent parent was 'Pimiento L'. 'Mississippi Nemaheart' is a root-knot nematode-resistant, pimento-type cultivar that was released by Mississippi State University in 1966 (Fery and Dukes, 1996; Hare, 1957, 1966). 'Pimiento L' was introduced by the Petoseed Company in the late 1960 s; it is susceptible to root-knot nematodes. The 'Pimiento L' accession that was used as the recurrent parental line for the current release was obtained from Willhite Seed, Inc. (Poolville, TX). PA-566 was derived from a single BC3F2 plant grown in 2005 .

Received for publication 15 July 2010. Accepted for publication 4 Oct. 2010.

The technical assistance of Floyd P. Maguire and Sharon Buckner, ARS-USDA, is gratefully acknowledged.

${ }^{1}$ To whom reprint requests should be addressed; e-mail Richard.Fery@ars.usda.gov. plant habit (height $=42 \mathrm{~cm}$; width $=54 \mathrm{~cm}$ ) and produces heart-shaped, dark red fruit (Table 1). The foliage is dense and the fruits are well protected from sun scald. The period from transplanting to first harvest of mature fruit is $\approx 78 \mathrm{~d}$ at Charleston, SC. There is position at anthesis is pendant. Corolla color is white with yellow throat markings, corolla spots are absent, and the stamens have white filaments and blue anthers. At full anthesis, the style length is usually the same length as the stamens. The lanceolate-shaped leaves are medium-sized and have a medium green color. The stems and leaves are glabrous. There is no visible presence of anthocyanin on the stems, branches, petioles, or pedicels. The fruits are attached to the pedicel in a pendant manner (typically one fruit per cluster); the calyx margin shape is almost smooth for ripe fruit (midway between smooth and dentate for green fruit); the annular constriction at the junction of the calyx and pedicel is absent; and the pedicels are short to intermediate in length, curved, and thick. The fruits are persistent, i.e., the pedicel and calyx usually remain with the fruit at harvest.

The results of three replicated field studies conducted in 2007, 2008, and 2009 at Charleston, SC, indicate that the fruit characteristics of PA-566 are equal to or superior to those of 'Pimiento L' (Table 2). PA-566 fruits were $9.0 \%$ heavier, $5.4 \%$ wider, and exhibited $6.6 \%$ thicker fruit walls. A typical PA-566 fruit weighs $84.4 \mathrm{~g}$ and is conical- or heart-shaped $(6.05 \mathrm{~cm}$ wide $\times 7.77 \mathrm{~cm}$ long) (Fig. 2). The shape of the pedicel attachment end of the fruit is truncate, the neck at the base of the fruit is absent, and the shape at the blossom end of the fruit is pointed. The cross-section of a typical fruit exhibits a slightly corrugated shape. The fruit wall is thick $(4.84 \mathrm{~mm})$. The color of immature fruit is dark green (Munsell color rating: $5.6 \mathrm{GY}$ 4.3/4.9); the color of harvest-stage fruits is usually one pedicel per axil and the pedicel
Fig. 1. Pedigree of the root-knot nematode-resistant, pimento-type pepper advance breeding line PA-566.
Table 1. Average plant height, plant width, days to harvest, and marketable fruit yield for the root-knot nematode-resistant, pimento-type breeding line PA-566 and the root-knot nematode-susceptible pimento-type cultivar Pimiento L grown in three separate trials at Charleston, SC, 2007-2009. ${ }^{\text {. }}$

\begin{tabular}{|c|c|c|c|c|}
\hline $\begin{array}{l}\text { Trial/pepper } \\
\text { Accession }\end{array}$ & Plant ht (cm) & $\begin{array}{l}\text { Plant width } \\
\text { (cm) }\end{array}$ & $\begin{array}{c}\text { Days to } \\
\text { harvest (no.) }\end{array}$ & $\begin{array}{l}\text { Marketable fruit } \\
\text { yield }\left(\mathrm{kg} \cdot \mathrm{ha}^{-1}\right)\end{array}$ \\
\hline \multicolumn{5}{|l|}{ Trial I } \\
\hline PA-566 & $48.8 \mathrm{a}^{\mathrm{y}}$ & $60.5 \mathrm{a}$ & $79.7 \mathrm{a}$ & $11,231 \mathrm{a}$ \\
\hline Pimiento L & $49.5 \mathrm{a}$ & $60.3 \mathrm{a}$ & $82.0 \mathrm{a}$ & $12,303 \mathrm{a}$ \\
\hline \multicolumn{5}{|l|}{ Trial II } \\
\hline PA-566 & $37.7 \mathrm{a}$ & $49.7 \mathrm{a}$ & $71.2 \mathrm{a}$ & $12,282 \mathrm{~b}$ \\
\hline Pimiento L & $39.5 \mathrm{a}$ & $50.8 \mathrm{a}$ & $71.2 \mathrm{a}$ & $15,077 \mathrm{a}$ \\
\hline \multicolumn{5}{|l|}{ Trial III } \\
\hline PA-566 & - & - & $85.6 \mathrm{a}$ & $11,014 \mathrm{~b}$ \\
\hline Pimiento L & - & - & $80.3 \mathrm{a}$ & $16,636 \mathrm{a}$ \\
\hline \multicolumn{5}{|c|}{ Combined analysis of all trials } \\
\hline PA-566 & 41.9 a NS & 53.7 a NS & 78.4 a NS & $11,573 b^{*}$ \\
\hline Pimiento L & $43.3 \mathrm{a}$ & $54.4 \mathrm{a}$ & $77.1 \mathrm{a}$ & $14,700 \mathrm{a}$ \\
\hline
\end{tabular}

${ }^{\mathrm{z}}$ The experimental design of each trial was a randomized complete block with six (Trial I), nine (Trial III), or 10 (Trial II) replications. Single-row plots were used for all trials ( 10 plants $/ \mathrm{plot}, 30 \mathrm{~cm}$ between plants, and $102 \mathrm{~cm}$ between rows). All trials were established using transplants; Trial I was planted on 2 May 2007, Trial II was planted on 6 May 2008, and Trial III was planted on 25 June 2009. Trial I was harvested five times (16 July 2007 to 14 Aug. 2007), and Trials II and III were each harvested six times (15 July 2008 to 19 Aug. 2008 and 9 Sept. 2009 to 20 Oct. 2009, respectively).

${ }^{y}$ Mean separation within columns and trials by Student-Newman-Keuls multiple range test, $P \leq 0.05$. Ns, *Non-significant or significant interaction between accession and trial at $P \leq 0.05$. 
Table 2. Comparison of fruit characteristics of the southern root-knot nematode-resistant, pimento-type pepper breeding line PA-566 and the root-knot nematode-susceptible, pimento-type pepper cultivar Pimiento L grown in three separate trials at Charleston, SC, 2007-2009.

\begin{tabular}{|c|c|c|c|c|c|}
\hline \multirow[b]{2}{*}{$\begin{array}{l}\text { Trial/pepper } \\
\text { accession }\end{array}$} & \multicolumn{5}{|c|}{ Fruit characteristic } \\
\hline & Width $(\mathrm{cm})$ & Length $(\mathrm{cm})$ & $\begin{array}{l}\text { Wall thickness } \\
(\mathrm{mm})\end{array}$ & $\begin{array}{l}\text { Locules } \\
\text { (no.) }\end{array}$ & $\begin{array}{c}\text { Fruit size } \\
\text { (g/fruit) }\end{array}$ \\
\hline \multicolumn{6}{|l|}{ Trial I } \\
\hline PA-566 & $6.25 \mathrm{a}^{\mathrm{z}}$ & $8.08 \mathrm{a}$ & $4.83 \mathrm{a}$ & $3.08 \mathrm{a}$ & $88.8 \mathrm{a}$ \\
\hline Pimiento L & $5.72 \mathrm{~b}$ & $8.03 \mathrm{a}$ & $4.22 \mathrm{~b}$ & $2.92 \mathrm{a}$ & $73.0 \mathrm{~b}$ \\
\hline \multicolumn{6}{|l|}{ Trial II } \\
\hline PA-566 & $6.09 \mathrm{a}$ & $7.66 \mathrm{a}$ & $4.16 \mathrm{a}$ & $3.10 \mathrm{a}$ & $83.2 \mathrm{a}$ \\
\hline Pimiento L & $5.94 \mathrm{a}$ & $7.67 \mathrm{a}$ & $4.33 \mathrm{a}$ & $2.78 \mathrm{~b}$ & $81.4 \mathrm{a}$ \\
\hline \multicolumn{6}{|l|}{ Trial III } \\
\hline PA-566 & $5.87 \mathrm{a}$ & $7.67 \mathrm{a}$ & $5.61 \mathrm{a}$ & $3.09 \mathrm{a}$ & $82.5 \mathrm{a}$ \\
\hline Pimiento L & $5.52 \mathrm{a}$ & $7.70 \mathrm{a}$ & $4.99 \mathrm{~b}$ & $2.84 \mathrm{a}$ & $75.6 \mathrm{a}$ \\
\hline \multicolumn{6}{|c|}{ Combined analysis of all trials } \\
\hline PA-566 & 6.05 a NS & 7.77 a NS & $4.84 \mathrm{a}^{* *}$ & $3.09 \mathrm{a} \mathrm{NS}$ & 84.4 a NS \\
\hline Pimiento L & $5.74 \mathrm{~b}$ & $7.77 \mathrm{a}$ & $4.54 \mathrm{~b}$ & $2.84 \mathrm{~b}$ & $77.4 \mathrm{~b}$ \\
\hline
\end{tabular}

${ }^{\mathrm{z}}$ Mean separation within columns and trials by Student-Newman-Keuls multiple range test, $P \leq 0.05$. NS, **Non-significant or significant interaction between accession and trial at $P \leq 0.01$.

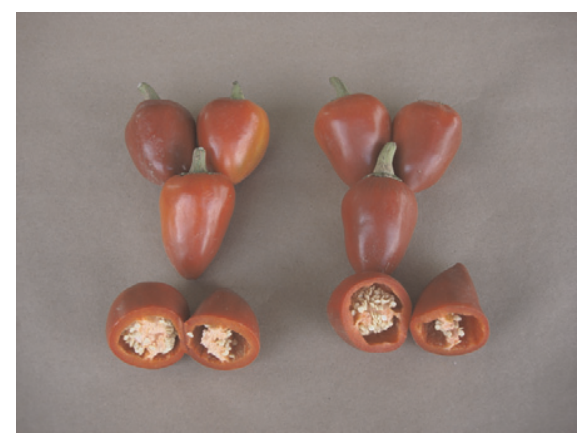

Fig. 2. Freshly harvested fruit of the root-knot nematode-susceptible, pimento-type pepper cultivar Pimiento L (left) and the root-knot nematode-resistant, pimento-type pepper advanced breeding line PA-566 (right)

a deep dark red (Munsell color rating: 5.9 R 3.5/7.4). The fruits are sweet (non-pungent), and a typical fruit has three locules. Over the 3-year period, PA-566 exhibited a respectable marketable fruit yield of $11,573 \mathrm{~kg} \cdot \mathrm{ha}^{-1}$. However, there was a significant interaction between genotype and trial with PA-566 yielding significantly less than 'Pimiento L' in 2 of the 3 years.

PA-566 is homozygous for the dominant $N$ gene that conditions a high level of resistance to root-knot nematodes. PA-566 has exhibited a high level of resistance to the southern root-knot nematode in all greenhouse tests; the numbers of galls and egg masses on the roots have always been minimal (Table 3). The resistance exhibited by PA-566 is equal to that exhibited by the rootknot nematode-resistant, bell-type cultivar Charleston Belle (Fery et al., 1998). Thies and Fery (2000) used two isogenic sets of bell pepper lines (differing at the $N$ locus) to demonstrate that the $N$ gene also conditions a high level of resistance to both the peanut be noted that the $N$-gene-mediated root-knot nematode resistance trait exhibited by the 'Mississippi Nemaheart' donor parent has remained highly effective for over 44 years since the cultivar was released.

The root-knot nematode-resistant PA-566 is recommended for use as a parental line by pepper breeders interested in developing root-knot nematode-resistant cultivars of pimento-type peppers. The dominant nature of the gene conditioning the root-knot nematode resistance trait would make PA-566 useful as an inbred parent for development of rootknot nematode-resistant F1 hybrids. PA-566 is a relatively well-adapted, pimento-type pepper and is potentially useful in commercial production without further development. It is particularly recommended for trial for the organic, specialty crop, and home garden markets because these segments of the pepper industry do not have easy access to alternative production sites or nematicides and nematicide application equipment. PA-566 should be expected to perform well in all areas where 'Pimiento L' has been grown successfully.

\section{Availability}

Small seed samples of PA-566 are available from the senior author for distribution to all interested research personnel and bona fide pepper seed producers. Genetic material of this release will be deposited in the National Plant Germplasm System where it will be available for research purposes, including the development and commercialization of new cultivars. It is requested that and tropical root-knot nematodes. It should
Table 3. Average root-gall index and average egg mass index for PA-566, 'Pimiento L' (susceptible recurrent parent), 'Charleston Belle' (resistant control), and 'Keystone Resistant Giant' (susceptible control) plants grown in soil infested with the southern root-knot nematode, Meloidogyne incognita race 3 (Greenhouse Experiment, 2008). ${ }^{\mathrm{z}}$

\begin{tabular}{lcc}
\hline $\begin{array}{l}\text { Pepper } \\
\text { accession }\end{array}$ & Gall index $^{\mathrm{y}}$ & $\begin{array}{c}\text { Egg mass } \\
\text { index }^{\mathrm{x}}\end{array}$ \\
\hline PA-566 & $1.02 \mathrm{~b}^{\mathrm{w}}$ & $1.02 \mathrm{~b}$ \\
Pimiento L & $4.73 \mathrm{a}$ & $4.52 \mathrm{a}$ \\
Charleston Belle & $1.37 \mathrm{~b}$ & $1.37 \mathrm{~b}$ \\
Keystone Resistant & $4.75 \mathrm{a}$ & $4.63 \mathrm{a}$ \\
$\quad$ Giant & &
\end{tabular}

${ }^{\mathrm{z}}$ Randomized complete-block experiment with six replications (five plants per plot; seeds planted on 22 Feb. 2008; seedlings transplanted into a steampasteurized mixture of soil, sand, and peat on 6 Mar. 2008; soil surrounding roots of each seedling was infested with $3000 \mathrm{M}$. incognita race 3 eggs on 18 Mar. 2008; and roots of all plants removed from the growth media on 17 June 2008 for evaluation for galling and egg masses).

${ }^{\mathrm{y}}$ Rated on a scale of 1 to $5: 1=$ no galls; $2=$ light galling, $1 \%$ to $25 \%$ of root system galled; $3=$ moderate galling, $26 \%$ to $50 \%$ of root system galled; 4 = heavy galling, $51 \%$ to $80 \%$ of root system galled; and $5=$ severe galling, $81 \%$ to $100 \%$ of root system galled.

${ }^{\mathrm{x}}$ Rated on a scale of 1 to $5: 1=$ no egg masses evident, 2 = scattered egg masses covering $1 \%$ to $25 \%$ of root system, $3=$ moderate number of egg masses covering $26 \%$ to $50 \%$ of root system, $4=$ numerous egg masses covering $51 \%$ to $80 \%$ of root system, and $5=$ extremely large number of egg masses covering $81 \%$ to $100 \%$ of root system.

${ }^{\text {w} M e a n ~ s e p a r a t i o n ~ w i t h i n ~ c o l u m n s ~ b y ~ S t u d e n t-~}$ Newman-Keuls multiple range test, $P \leq 0.05$.

appropriate recognition of source be given when this germplasm contributes to research or development of a new breeding line or cultivar.

\section{Literature Cited}

Fery, R.L. and P.D. Dukes. 1996. The inheritance of resistance to the southern root-knot nematode in 'Carolina Hot' cayenne pepper. J. Amer. Soc. Hort. Sci. 121:1024-1027.

Fery, R.L., P.D. Dukes, and J.A. Thies. 1998. 'Carolina Wonder' and 'Charleston Belle': Southern root-knot nematode-resistant bell peppers. HortScience 33:900-902.

Hare, W.W. 1957. Inheritance of resistance to rootknot nematode in pepper. Phytopathology 47: 455-459.

Hare, W.W. 1966. New pimiento is resistant to nematodes. Mississippi Farm Res. 29:1,8.

Thies, J.A. and R.L. Fery. 2000. Characterization of resistance conferred by the $N$ gene to Meloidogyne arenaria races 1 and 2, M. hapla, and $M$. javanica in two sets of isogenic lines of Capsicum annuum L. J. Amer. Soc. Hort. Sci. 125:71-75. 